\title{
Leveraging Genomics for Head and Neck Cancer Treatment
}

\author{
Journal of Dental Research \\ 2018, Vol. 97(6) 603-613 \\ (C) International \& American Associations \\ for Dental Research 2018 \\ Reprints and permissions: \\ sagepub.com/journalsPermissions.nav \\ DOI: $10.1177 / 0022034518756352$ \\ journals.sagepub.com/home/jdr
}

\author{
J.D. Kemmer', D.E. Johnson', and J.R. Grandis'
}

\begin{abstract}
The genomic landscape of head and neck squamous cell carcinoma (HNSCC) has been recently elucidated. Key epigenetic and genetic characteristics of this cancer have been reported and substantiated in multiple data sets, including those distinctive to the growing subset of human papilloma virus (HPV)-associated tumors. This increased understanding of the molecular underpinnings of HNSCC has not resulted in new approaches to treatment. Three Food and Drug Administration-approved molecular targeting agents are currently available to treat recurrent/metastatic disease, but these have exhibited efficacy only in subsets of HNSCC patients, and thus surgery, chemotherapy, and/or radiation remain as standard approaches. The lack of predictive biomarkers to any therapy represents an obstacle to achieving the promise of precision medicine. This review aims to familiarize the reader with current insights into the HNSCC genomic landscape, discuss the currently approved and promising molecular targeting agents under exploration in laboratories and clinics, and consider precision medicine approaches to HNSCC.
\end{abstract}

Keywords: squamous cell carcinoma of head and neck, head and neck neoplasms, precision medicine, biomarkers, human papillomavirus, molecular targeted therapy

\section{Introduction}

Head and neck squamous cell carcinoma (HNSCC) accounts for $90 \%$ of head and neck cancers and is the sixth most common type of cancer globally (Torre et al. 2015). It is associated with significant morbidity and mortality, and the 5-y survival rates for HNSCC have remained between $40 \%$ and $60 \%$ for the past 4 decades (Siegel et al. 2017). Risk factors for HNSCC include tobacco and alcohol use, which can have synergistic effects, as well as infection with human papilloma virus (HPV; Kreimer et al. 2005; Hashibe et al. 2009). In addition, there is some evidence of an association between Epstein-Barr viral infection and oral SCC (She et al. 2017). While the incidence of tobaccoassociated HNSCC has been on the decline in recent years because of decreasing tobacco use, the incidence of HPVassociated HNSCC is on the rise (Chaturvedi et al. 2011).

Despite improvements in surgical techniques and radiation delivery, treatment options remain surgery and/or chemoradiation therapy based on anatomic location and TNM staging. This model of care fails to recognize the vast molecular heterogeneity that is associated with these malignancies and the effect that these biological differences can have on response to treatment. Currently, cetuximab, a monoclonal antibody against epidermal growth factor receptor (EGFR), is the only molecular targeting therapeutic approved by the Food and Drug Administration (FDA) for use in newly diagnosed disease in conjunction with chemotherapy or radiation treatment, yet the efficacy of this drug is limited (Bonner et al. 2010). More recently, the development of molecular targeting agents against checkpoint proteins expressed on immune cells has rapidly gained traction. Pembrolizumab and nivolumab are monoclonal antibodies that target the programmed death protein 1 (PD-1) checkpoint protein. Both received FDA approval in 2016 for use in recurrent or metastatic HNSCC, and many other immune checkpoint inhibitors are being tested in ongoing clinical trials (Ferris et al. 2016; Seiwert et al. 2016). An advancement in our molecular understanding of this disease is required for the employment of effective precision medicine tools. Aiding in this goal is The Cancer Genome Atlas (TCGA), a publically available database developed by the National Institutes of Health and the National Human Genome Research Institute in 2005 with the purpose of cataloging the genomic landscape of many cancer types. As of the most recent update, 528 HNSCC patient tumors have been sequenced by TCGA (Cerami et al. 2012; Gao et al. 2013). These data can be used to propel preclinical studies, further illuminating the roles of high-frequency gene mutations or copy number alterations in tumorigenesis and tumor progression.

This review aims to provide an overview of the genomic landscape of HNSCC, to discuss how this information has been applied to medical practice thus far, and to postulate what the future may hold for integrating genomics and therapy in HNSCC.

\footnotetext{
'Department of Otolaryngology-Head and Neck Surgery, University of California San Francisco, San Francisco, CA, USA

Corresponding Author:

J.R. Grandis, Department of Otolaryngology-Head and Neck Surgery, University of California San Francisco, 550 16th Street, 6th Floor, San Francisco, CA 94I43, USA.

Email: Jennifer.Grandis@ucsf.edu
} 


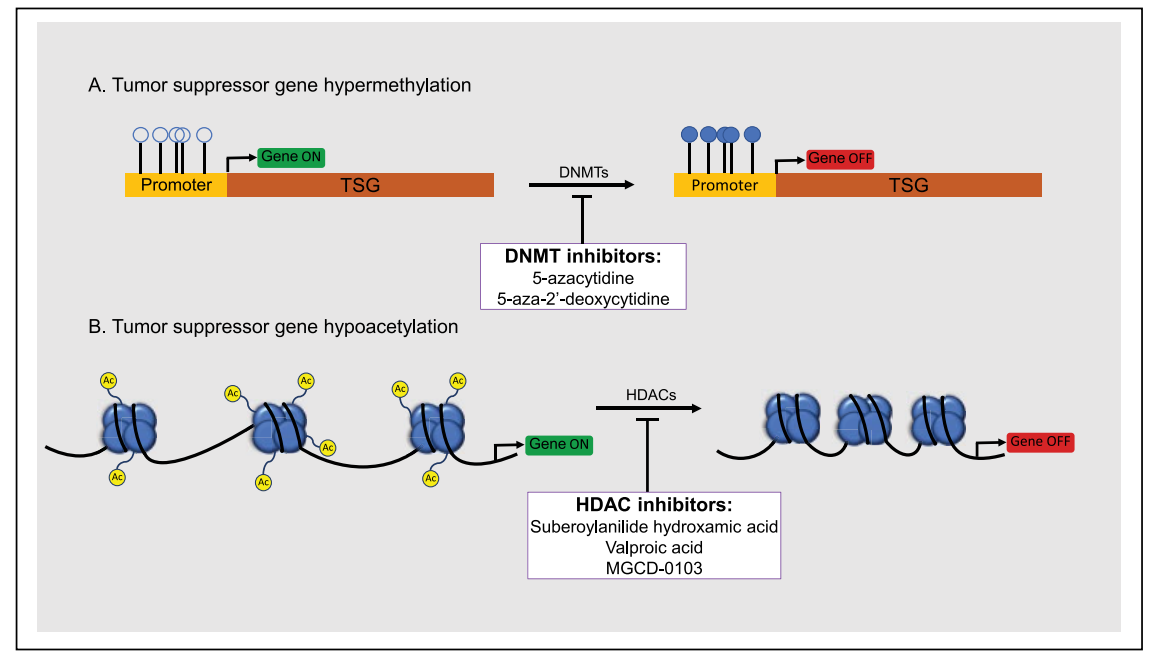

Figure I. Epigenetic alterations of tumor-suppressor genes in head and neck squamous cell carcinoma (HNSCC) and pipeline therapeutics. (A) Hypermethylation of promotor regions in tumor-suppressor genes, a common event in HNSCC, is associated with gene silencing, leading to events such as cell cycle proliferation, inhibition of apoptosis, and prevention of DNA repair mechanisms. DNA methyltransferases (DNMTs) are responsible for de novo methylation patterns causing hypermethylation. The DNMT inhibitor 5-azacytidine (Vidaza) is currently being assessed in a pilot study looking at the effect of this drug on patient-derived xenografts (PDXs) of human papilloma virus (HPV)-negative and HPV-positive HNSCC (NCT02 I78072), and this drug recently showed efficacy in the setting of HPV-positive HNSCC PDXs (Biktasova et al. 20I7). (B) Hypoacetylation of tumor-suppressor genes is another frequently seen epigenetic alteration of HNSCC. Histone deacetylase inhibitors (HDACis) are a rapidly growing class of anticancer drugs that have been shown to reestablish histone acetylation balance and thus restore expression of hypoacetylated genes (Le et al. 2014). Currently, clinical trials are underway to assess the efficacy of 3 different HDACis: suberoylanilide hydroxamic acid (vorinostat; NCT0 I06492 I, NCT025385 I0), valproic acid (valproate; NCT02608736), and MGCD-0I03 (mocetinostat; NCT0299399I).

\section{Epigenetics of HNSCC}

Epigenetic changes affecting gene expression include DNA methylation, histone acetylation, and expression of small noncoding RNAs. They are both heritable and reversible and have been implicated in many disease states, including cancer. In HNSCC, global hypomethylation has been associated with poorer prognosis (Baylin 1997). In addition, many tumor-suppressor genes, including $C D K N 2 A, C D H 1, M G M T$, and $R A S S F 1 A$, exhibit promoter hypermethylation, implicating epigenetic changes in head and neck tumor development (Koutsimpelas et al. 2012; Asokan et al. 2014). DNA methyltransferase (DNMT) inhibitors, such as 5-azacytidine (5-aza), act to reduce methylation of genomic DNA, resulting in induction of repressed tumor suppressors. Treatment with DNMT inhibitors has been shown to decrease the growth of xenograft tumors in mice and has been pursued as a means to improve response to radiation therapy (Chen et al. 2015; Biktasova et al. 2017).

Additional studies have discovered associations between treatment efficacy and specific epigenetic modifications. Nuclear factor kappa beta $(\mathrm{NF}-\kappa \mathrm{B})$ has been shown to induce resistance to cisplatin chemotherapy by inhibiting histone acetylation, such that tumor chromatin remains condensed, preventing downstream signaling via BRCA1 (Almeida et al. 2014). Similarly, several studies have described a hypoacetylated DNA profile in HNSCC (Le et al. 2014). In HNSCC preclinical models, treatment with histone deacetylase (HDAC) inhibitors decreases the number of cancer stem cells (Giudice et al. 2013). Although HDAC inhibitors have been largely inactive in clinical trials of solid tumors to date, combination approaches are being studied (Fig. 1; Lindsay et al. 2017).

\section{Mutational Landscape}

Determination of the genomic landscape of HNSCC led to the identification of several key genes that are frequently mutated in this disease. Common genomic changes in HNSCC include oncogenic mutations in PIK3CA and $H R A S$, as well as mutations in the tumorsuppressor genes TP53, CDKN2A, PTEN, and NOTCH1.

The $P I K 3 C A$ gene encodes the $\mathrm{p} 110 \alpha$ catalytic subunit of PI3 kinase (PI3K), an intracellular signaling protein that plays important roles in regulating cellular proliferation, motility, and survival. Both amplification and mutation of the PIK3CA gene have been identified in HNSCC (Pedrero et al. 2005; Qiu et al. 2006). The PI3K signaling pathway is negatively regulated by phosphatase and tensin homolog (PTEN; Vazquez and Sellers 2000). Loss of PTEN expression or loss of PTEN function due to mutation is common in HNSCC and is a potential marker of high recurrence risk (Mriouah et al. 2014). $H R A S$ is a proto-oncogene with multiple effector pathways, including the RAS-MEK-ERK pathway, which has been implicated in tumorigenesis (Castellano and Downward 2011).

Loss-of-function TP53 mutations are the most frequent gene mutations detected in HNSCC, with an $84 \%$ prevalence in HPV-negative tumors analyzed by TCGA (The Cancer Genome Atlas Network 2015). TP53 genetic alterations in HNSCC lead to either loss of expression or expression of a nonfunctional or dominant-negative p53. Thus, TP53 genetic alterations abrogate the normal role of p53 in the sensing/ repair of DNA damage or the induction of DNA damageinduced apoptosis. Many studies have suggested an early role for TP53 mutations in the multistep carcinogenesis process leading to HNSCC (el-Naggar et al. 1995). Like TP53, genetic loss of the tumor-suppressor gene $C D K N 2 A$, which encodes the cyclin-dependent kinase inhibitor p16/INK4A, is associated with HNSCC (Rothenberg and Ellisen 2012). This loss can occur via inactivating mutation, copy number loss, gene deletion, or hypermethylation of the promotor region. Sequencing by TCGA found that $58 \%$ of HPV-negative tumors harbor a $C D K N 2 A$ inactivating mutation, which is likely an underestimation of the loss of functional p16 expression when one accounts for epigenetic silencing (Vikram Bhatia et al. 
2014; Puram and Rocco 2015). NOTCH1 has been proposed as a tumorsuppressor gene in HNSCC, with mutations in this gene seen in $15 \%$ of tumors (Agrawal et al. 2011). The NOTCHI protein is a transmembrane receptor that has important roles in embryonic development and cell differentiation. Although there is significant recent evidence supporting its role as a tumor suppressor in HNSCC, in other types of cancer NOTCH1 promotes initiation and progression of tumor growth and induction of angiogenesis (Agrawal et al. 2011; Stransky et al. 2011; Yap et al. 2015). The NOTCH1 pathway has been further implicated in HNSCC by Sun et al. (2014), who supported a bimodal pattern of alteration, including inactivating NOTCH1 receptor mutations and increased NOTCH1 expression due to amplification of the NOTCH1 gene.

Sequencing by TCGA has also revealed frequent mutations in a number of understudied genes, including mutations in FAT1, AJUBA, CASP8, NSD1, $K M T 2 D, H L A-A$, and TGFBR2 (The Cancer Genome Atlas Network 2015). FAT1, or FAT atypical cadherin 1, has been implicated as a tumor-suppressor gene that normally acts to prevent nuclear localization of betacatenin. Thus, mutation of this gene could result in promotion of WNT signaling (Morris et al. 2013). FAT1 loss-of-function mutations have been linked to better overall survival in patients with HPV-negative HNSCC (Kim et al. 2016). Like FAT1, AJUBA has been shown to negatively regulate the WNT signaling pathway (Haraguchi et al. 2008). Caspase-8 (CASP8) mutations in HNSCC have been shown to inhibit death-receptor-mediated cell death and promote the activation of NF- $\mathrm{kB}$ (Ando et al. 2013; Li et al. 2014). In addition, CASP8 mutations have been shown to promote tumor growth, invasion, and migration. The TCGA data set revealed that tumors harboring CASP 8 mutations exhibited fewer CNAs and often had concurrent HRAS mutations (Pickering et al. 2013). NSD1, or nuclear receptor binding SET domain protein 1, is a histone methyltransferase gene (Histone 3 Lysine 6) found by TCGA to harbor loss-of-function or truncating mutations in HNSCC. Loss of NSD1 can prevent cellular differentiation and promote oncogenesis; mutation of this gene has been validated in additional HNSCC datasets (Papillon-Cavanagh et al. 2017). Similarly, histone-lysine N-methyltransferase 2D (KMT2D, also known as MLL2) is another histone methyltransferase, further highlighting the significance of epigenetic changes in HNSCC. KMT2D promotes gene expression by maintaining an open-chromatin state, and its mutation has been linked to developmental disease and several cancers (Froimchuk et al.
2017). Mutations found in HLA-A and transforming growth factor beta receptor 2 (TGFBR2) may play crucial roles in enhancing immune evasion (Feenstra et al. 1999; Massagué 2008). Integrating data from TCGA along with smaller-scale HNSCC genomic studies conducted prior and post TCGA allows for a clearer picture of the complex nature of this heterogeneous cancer (Fig. 2).

\section{Differential Genomics: HPV+ versus HPV-}

HPV-associated (HPV+) HNSCC accounts for an increasing number of HNSCC cases, namely, oropharyngeal HNSCCs, of which $64 \%$ in TCGA were HPV+ (The Cancer Genome Atlas Network 2015; Carlander et al. 2017). The rapid rise in HPVassociated HNSCC is crucial because HPV + and HPV-negative (HPV-) HNSCC vary in their mutational landscapes, prognosis, and effective molecular targeted treatment options. HPVdriven carcinogenesis is largely due to 2 oncoproteins encoded by the viral genome, E6 and E7, which confer genomic instability by abrogating the expression of p53 and retinoblastoma $(\mathrm{Rb})$, respectively (Dyson et al. 1989; Scheffner et al. 1990). Overall, HPV+ head and neck cancers harbor a mutational burden that is similar if not lower than their HPV- counterparts (Stransky et al. 2011; Seiwert et al. 2015). It is well documented that $\mathrm{HPV}+$ cancers exhibit improved overall survival, 
reduced recurrence, and better response to chemoradiation than HPV-HNSCC (Fakhry et al. 2008; Ang et al. 2010).

TP53 mutation is rarely seen in HPV+ HNSCC, likely because of the role that the E6 protein plays in promoting proteasomal degradation of wild-type p53 (Feldman et al. 2016). This suggests that unlike non-HPV-associated cancers, which rely on mutational loss of function of the TP53 gene to promote tumorigenesis, HPV+ cancers rely on viral proteins to cause functional loss of $\mathrm{p} 53$. In addition, several studies suggest that there is a higher prevalence of PIK3CA activating mutations in HPV+ HNSCC (Chiosea et al. 2013; The Cancer Genome Atlas Network 2015).

Two genetic alterations that may be unique to HPV+ HNSCC have been identified in TCGA and supported in subsequent studies. Deletion or truncation of tumor necrosis factor receptor-associated factor 3 (TRAF3) occurs in $22 \%$ and E2F1 amplification in 19\% of HPV+ tumors in the TCGA data set (The Cancer Genome Atlas Network 2015). TRAF3 and cylindromatosis lysine 63 deubiquitinase (CYLD) genes also exhibit significant rates of mutation in HPV+ HNSCC, and interestingly, loss-of-function mutations in these genes result in constitutive activation of the NF- $\mathrm{kB}$ pathway (Hajek et al. 2017).

\section{Mutational Landscape of Recurrent and Metastatic Tumors}

Recent investigations have revealed that recurrent and metastatic HNSCC generally harbor shared driver mutations with their primary tumor counterparts, while also accumulating additional novel mutations. Notably, Morris et al. (2017) found significantly higher rates of TERT promoter mutations in recurrent or metastatic HPV- HNSCC as compared with primary HPV- tumors, resulting in increased telomerase expression. This finding is consistent with the high prevalence of TERT promoter mutations in advanced solid tumors of varying types, suggesting a role for these mutations in progression and aggressiveness of disease (Zehir et al. 2017). In this same study, nearly half of recurrent HPV+ tumors were found to exhibit a mutational profile more similar to primary HPVtumors than primary HPV+ tumors. Predictably, these "HPV negative-like" recurrent HPV+ tumors trended toward poorer survival. Overall, recurrent HPV+ tumors were enriched for TP53 mutations and whole-genome duplication and lacking in PIK3CA mutations compared with their primary counterparts (Morris et al. 2017).

\section{FDA-Approved Molecular Targeting Agents}

The EGFR is a transmembrane tyrosine kinase that binds epidermal growth factor and activates pathways leading to increased cell division and proliferation. Overexpression of EGFR due to gene amplification and its role as a prognostic factor have been well described in HNSCC (Keren et al. 2014). Cetuximab is a chimeric monoclonal antibody directed against
EGFR and is FDA-approved as a first-line treatment in combination with platinum-based chemotherapy for recurrent or metastatic HNSCC (Vermorken et al. 2008). Since approval, clinical response to cetuximab has been underwhelming, with efficacy in only a small subset of patients. Unfortunately, this lack of response is complicated by a lack of predictive biomarkers of response, as well as evidence indicating that $E G F R$ gene copy number is not associated with response to cetuximab treatment (Licitra et al. 2011). Cetuximab efficacy is blunted by a high rate of intrinsic or acquired drug resistance. Currently, convincing clinical data supporting predictive biomarkers of response to cetuximab treatment are limited to secondary analysis of a phase III clinical trial by Weidhass and colleagues (2017), showing that a functional germline mutation in the $3^{\prime}$ untranslated region of $K R A S$ may predict a positive response to cetuximab treatment. Identification of predictive biomarkers of response to cetuximab treatment will prove crucial to the future application of this molecular targeting agent, as will development of new agents or combination therapies to prevent or overcome resistance (Table 1).

Congruent with the cancer immunotherapy movement, pembrolizumab and nivolizumab, monoclonal antibodies against PD-1, received FDA approval in 2016 for treatment of recurrent or metastatic HNSCC that does not respond to platinum chemotherapy (Ferris et al. 2016; Seiwert et al. 2016). There is significant evidence describing the role of immune surveillance in prevention of head and neck cancers. However, when neoplastic cells arise, tumors develop mechanisms of immune evasion such as secretion of immunosuppressive cytokines, including factors that upregulate PD-L1 expression (Zolkind and Uppaluri 2017). HNSCC tumors tend to exhibit a high level of immune infiltration compared with other cancer types, and in fact, the most highly immune-infiltrated head and neck tumors exhibit better patient outcomes (Mandal et al. 2016). Although initial clinical trials testing pembrolizumab and nivolumab were promising enough to warrant FDA approval, response rates to these immune checkpoint inhibitors remain low (10\% to $20 \%)$, and thus, it is crucial that biomarkers are developed to recognize patients who are most likely to benefit from these treatments (Table 1).

\section{Development of Novel Targeting Agents Based on the HNSCC Genomic Landscape}

Several large studies reported the HNSCC genomic landscape. However, leveraging this information to guide therapy requires additional investigation. Head and neck oncology has lagged to date compared with other cancers in the field of precision medicine. The OncoKB database represents a tool to facilitate interpretation of genomic alterations and support evidencebased decision making in the use of molecular targeting agents (Chakravarty et al. 2017). OncoKB allows physicians to search a database of cancer genes and find applicable drugs for which those cancer type-specific gene variants have been shown to act as a biomarker. Each biomarker is assigned a corresponding 
Table I. Food and Drug Administration (FDA)-Approved Targeted Therapies.

\begin{tabular}{|c|c|c|c|c|}
\hline Therapy & $\begin{array}{l}\text { Year of FDA } \\
\text { Approval }\end{array}$ & Indication & $\begin{array}{l}\text { Predictive Biomarker Status } \\
\text { in Clinical Studies }\end{array}$ & Supporting Research \\
\hline \multirow[t]{4}{*}{$\begin{array}{r}\text { Cetuximab } \\
\text { (Erbitux) }\end{array}$} & \multirow[t]{4}{*}{2006} & \multirow{4}{*}{$\begin{array}{l}\text { Cetuximab + radiotherapy in } \\
\text { locally advanced HNSCC; } \\
\text { cetuximab + platinum-based } \\
\text { chemotherapy in recurrent or } \\
\text { metastatic HNSCC }\end{array}$} & $\begin{array}{l}\text { KRAS variant HNSCC may predict better } \\
\text { response in patients treated with } \\
\text { cetuximab + cisplatin }\end{array}$ & Weidhaas et al. 2017 \\
\hline & & & $\begin{array}{l}\text { EGFR-K52I polymorphism may predict } \\
\text { cetuximab resistance in patients }\end{array}$ & Braig et al. 2017 \\
\hline & & & $\begin{array}{l}\text { Lower pAKT expression resulted in improved } \\
\text { survival in patients treated with cetuximab } \\
\text { and chemotherapy }\end{array}$ & Lyu et al. 2016 \\
\hline & & & $\begin{array}{l}\text { Lower PTEN expression resulted in worse } \\
\text { survival in patients treated with cetuximab } \\
\text { and chemotherapy }\end{array}$ & da Costa et al. 2015 \\
\hline \multirow[t]{3}{*}{$\begin{array}{l}\text { Pembrolizumab } \\
\text { (Keytruda) }\end{array}$} & \multirow[t]{3}{*}{2016} & \multirow[t]{3}{*}{ Recurrent or metastatic HNSCC } & $\begin{array}{l}\text { A combination of PD-LI-positive tumors } \\
\text { cell and PD-LI-positive inflammatory } \\
\text { cells in recurrent/metastatic HNSCC may } \\
\text { have better response to pembrolizumab } \\
\text { treatment (but this is not predicted by PD- } \\
\text { LI-positive tumors alone) }\end{array}$ & Chow et al. 2016 \\
\hline & & & $\begin{array}{l}\text { PD-LI-positive tumors may be more likely } \\
\text { to respond to pembrolizumab treatment in } \\
\text { recurrent/metastatic HNSCC }\end{array}$ & Seiwart et al. 2016 \\
\hline & & & $\begin{array}{l}\text { Expression of } 6 \text { interferon- } \gamma-\text { related genes in } \\
\text { recurrent/metastatic HNSCC may predict } \\
\text { response to pembrolizumab treatment }\end{array}$ & Seiwart et al. 2016 \\
\hline $\begin{array}{l}\text { Nivolumab } \\
\text { (Opdivo) }\end{array}$ & 2016 & $\begin{array}{l}\text { Recurrent or metastatic HNSCC } \\
\text { refractory to platinum-based } \\
\text { chemotherapy }\end{array}$ & $\begin{array}{l}\text { PD-LI and pl6 expression levels not } \\
\text { significantly associated with overall survival } \\
\text { in patients treated with nivolumab }\end{array}$ & Ferris et al. 2016 \\
\hline
\end{tabular}

Abbreviations: EGFR, epidermal growth factor receptor; FDA, Food and Drug Administration; HNSCC, head and neck squamous cell carcinoma; PTEN, phosphatase and tensin homolog.

level of evidence on a 1 to 4 scale, based on FDA recognition and clinical evidence. According to this database, the only identified biomarker applicable to HNSCC is the KRAS variant, classified at evidence level 4, yet KRAS mutation is rare in HNSCC (Chakravarty et al. 2017).

\section{EGFR Targeting}

As discussed above, targeting the oncogenic effects of EGFR overexpression in HNSCC has proved challenging, and cetuximab efficacy is limited to a small, currently unpredictable subset of patients. This finding has led to the hypothesis that selectively targeting EGFR may drive cross-talk within the ErbB receptor family and promote signaling via other receptor family members (Shepard et al. 2008). Supporting this theory are results from phase II and phase III clinical trials of afatinib, an irreversible ErbB family blocker. The phase II trial showed comparable antitumor effects to cetuximab and significantly improved progression-free survival (PFS) of recurrent/metastatic and platinum-refractory HNSCC compared with methotrexate (MTX), while the phase III clinical trial (LUX-Head \& Neck 1) showed improved PFS as compared with MTX in the same study population (Seiwert et al. 2014; Machiels et al. 2015). Biomarker analyses of the LUX-Head \& Neck 1 trial showed improved PFS in afatinib-treated patients versus MTX-treated patients when their tumors were p16-negative, EGFR-amplified, HER3-low, and PTEN-high (Cohen et al. 2017). In addition, a preclinical study identified high levels of
AKT-phosphorylation as predictive of anti-EGFR drug resistance in HNSCC cell lines (Silva-Oliveira et al. 2017). There is a continued search for more efficacious novel EGFR inhibitors to treat HNSCC.

\section{PI3K-AKT-mTOR Pathway Targeting}

Since early identification of highly prevalent driver mutations in the PI3K-AKT-mTOR pathway, this has been a popular target for therapeutic intervention. Initial preclinical studies demonstrated antitumor efficacy of PI3K inhibitors, prompting many HNSCC clinical trials of PIK3 inhibitors as monotherapy or in combination with other agents (Isaacsson et al. 2015). The irreversible PI3K inhibitor PX-866 has shown efficacy in preclinical models of HNSCC, specifically in tumors harboring PIK3CA mutations and, interestingly, Notch1 inactivating mutations (Keysar et al. 2013). A phase II clinical trial was conducted to assess the efficacy of PX-866 with docetaxel in patients with recurrent or metastatic HNSCC and showed no significant clinical benefit. Of note, only $8 \%$ of the patients enrolled in this study exhibited PIK3CA mutations, and no patients harbored KRAS mutations (Jimeno et al. 2015). In vitro data suggest that PIK3CA mutations may act as biomarkers to predict response to PIK3 inhibitors and lacking these mutations is predictive of nonresponse (Mazumdar et al. 2014). In contrast, treatment with the pan-PI3K inhibitor buparlisib in combination with paclitaxel demonstrated significantly improved PFS in patients with recurrent or metastatic HNSCC 
when compared with placebo with paclitaxel treatment in a phase II clinical trial (Soulières et al. 2017). There is evidence that PI3K inhibition may lead to feedback activation of other receptor tyrosine kinases suggesting that inhibition of PI3K will be ineffective as a monotherapy (Michmerhuizen et al. 2016). Resistance to PI3K inhibitors may develop due to PI3K/ AKT-independent upregulation of mammalian target of rapamycin (mTOR), perhaps due to overexpression of the receptor tyrosine kinase AXL; this suggests co-targeting PI3K and mTOR would be a promising strategy (Elkabets et al. 2015).

Despite promising preclinical findings, mTOR inhibitors have yet to successfully translate to clinical practice in HNSCC (Simpson et al. 2015). In a phase II clinical trial, the mTOR inhibitor everolimus did not show clinical benefit when used as monotherapy against recurrent or metastatic HNSCC, although no PI3K activating mutations were identified in tumor samples from the patients (Geiger et al. 2016). The type 2 diabetes mellitus drug metformin has been shown to indirectly inhibit mTOR, and in an epidemiologic study of 66,000 diabetic patients, the incidence of head and neck cancer was 34\% lower in patients taking metformin versus patients not taking metformin (Yen et al. 2015). These results led to a preclinical study showing a role for metformin in prevention of tumor growth via inhibition of mTOR signaling and a subsequent clinical trial to examine the efficacy of metformin in preventing development of HNSCC from precancerous lesions (NCT02581137; Madera et al. 2015).

\section{RAS/RAF/MEK/ERK Pathway Targeting}

Mitogen-activated protein kinase kinase (MEK) inhibition via MEK162 has been studied in vitro and in vivo and has been shown to decrease HNSCC tumor cell proliferation (Mazumdar et al. 2015). Furthermore, MEK inhibition has been shown to enhance PI3K/mTOR inhibition in a preclinical study (Mohan et al. 2015). RNA silencing of the overexpressed transmembrane glycoprotein CD147 decreased chemoresistance in HNSCC cell lines via deactivation of the MAPK/ERK signaling pathway (Ma et al. 2017).

\section{Other Pathways}

In an effort to target the CDKN2A deletions and CCND1 gene amplification that are seen in HNSCC, CDK4/6 inhibitors have been studied in preclinical models. The first clinical trial to evaluate a CDK4/6 inhibitor in HNSCC was reported in 2016 and determined the safety of palbociclib (PD 0332991, FDA approved for the treatment of ER+, HER2- metastatic breast cancer) in combination with cetuximab in patients with recurrent or metastatic disease (Michel et al. 2016). Based on the results of this study, which showed partial responses in the 2 patients with p16-negative tumors, there is an ongoing clinical trial assessing the efficacy of palbociclib in addition to cetuximab for treating incurable, p16-negative HNSCC (NCT02101034).
While many of these novel molecular targeting agents have failed to prove efficacious in clinical trials, the lack of precision in these attempts to test precision medicine approaches cannot go unnoticed. Going forward, trials of molecular targeting agents must be carefully designed to simultaneously evaluate potential biomarkers predicting response, allowing for subgroup analyses and revealing patients who may preferentially respond to a therapy based on specific characteristics of their genomic landscape. Table 2 highlights active clinical trials in the United States that are incorporating genetic information into clinical trial design via assessment of biomarkers as predictors of treatment response. Other trials are assessing the impact of biomarkers on treatment in a more targeted fashion-by limited inclusion criteria to individuals harboring specific genetic alterations or amplifications (Table 3).

\section{Molecular Co-targeting Strategies}

Because of the genetic heterogeneity of HNSCC and the propensity for drug resistance development with monotherapy, it is likely that combination therapy will prove most efficacious when implementing molecular targeting agents. To achieve therapeutic synergy, several possible approaches are possible and indeed are being tested in clinical trials including (1) targeting molecules within convergent signaling pathways, (2) targeting molecules with nonoverlapping mechanisms of action, and/or (3) targeting anti-tumorigenic molecules that act to synergize with conventional chemotherapy or radiation treatment. Such approaches can involve integration of methods to reverse effects of somatic tumor mutations, modulate deleterious epigenetic changes, and augment immune response against tumor cells.

Several co-targeting strategies described in the literature involve the combination of cetuximab with a more novel targeting approach. Because clinical responses to cetuximab are limited, there is an ongoing search for combination therapies that may sensitize resistant tumor cells to this EGFR inhibitor. One such example is the use of cetuximab in combination with PI3K inhibitors, which has shown preclinical efficacy (Bozec et al. 2017). In patients treated with cetuximab plus chemoradiation, worse overall survival and PFS has been associated with PI3K and RAS pathway activation, indicating that these pathways may play a role in cetuximab resistance (Psyrri et al. 2014). In clinical trials to date, the combination of PI3K inhibition and cetuximab treatment has not yet shown clinical efficacy in unselected patient populations (Jimeno et al. 2015). Similarly, there are promising results in preclinical studies suggesting a role for mTOR targeting in cetuximab-resistant HNSCC (Bozec et al. 2016; Lattanzio et al. 2016). PIK3CA mutations, RAS mutations, and high EGFR expression have been proposed to serve as predictive biomarkers of positive response to this co-targeting approach (Wang et al. 2014). Unfortunately, a phase II trial of everolimus and erlotinib showed good tolerability of this combination but lack of significant clinical benefit (Massarelli et al. 2015). 
Table 2. Currently Active U.S. Clinical Trials Evaluating Molecular Targeting Agents with Biomarker Studies Assessing Associations to Treatment Response.

\begin{tabular}{|c|c|c|c|c|}
\hline $\mathrm{NCT}$ & Phase & Interventions & Molecular Targeting Roles & Biomarkers to be Assessed \\
\hline NCT02I 24850 & Ib, recruiting & $\begin{array}{l}\text { Cetuximab }+ \text { motolimod } \pm \\
\text { nivolumab }\end{array}$ & $\begin{array}{l}\text { Anti-epidermal growth factor } \\
\text { receptor (EGFR) monoclonal } \\
\text { antibody; small-molecule agonist } \\
\text { of toll-like receptor 8; anti-PD-I } \\
\text { monoclonal antibody }\end{array}$ & $\begin{array}{l}\text { Immune biomarkers (NK, } \\
\text { mDC, T-cell activation and } \\
\text { tumor infiltration, and serum } \\
\text { cytokines) }\end{array}$ \\
\hline NCTOI 218048 & $\begin{array}{l}\text { II, ongoing but not } \\
\text { recruiting }\end{array}$ & $\begin{array}{l}\text { Cetuximab } \pm \text { surgical } \\
\text { resection, adjuvant } \\
\text { radiation, cisplatin, and/ } \\
\text { or carboplatin }\end{array}$ & Anti-EGFR monoclonal antibody & Immune biomarkers (unspecified) \\
\hline NCT02277I97 & $\begin{array}{l}\text { I, ongoing but not } \\
\text { recruiting }\end{array}$ & Ficlatuzumab + cetuximab & $\begin{array}{l}\text { Anti-hepatocyte growth factor } \\
\text { (HCG) IgGI monoclonal } \\
\text { antibody; anti-EGFR monoclonal } \\
\text { antibody }\end{array}$ & $\begin{array}{l}\text { Biomarkers of the HGF/cMet } \\
\text { pathway }\end{array}$ \\
\hline NCT00957853 & $\begin{array}{l}\text { II, ongoing but not } \\
\text { recruiting }\end{array}$ & $\begin{array}{l}\text { Cetuximab } \pm \text { IMC-AI } 2+ \\
\text { surgical resection }\end{array}$ & $\begin{array}{l}\text { Anti-EGFR monoclonal antibody; } \\
\text { anti-lgGI monoclonal antibody }\end{array}$ & $\begin{array}{l}\text { Various biomarkers, including } \\
\text { phospho-Akt }\end{array}$ \\
\hline NCT03I53982 & II, not yet recruiting & $\begin{array}{l}\text { Ruxolitinib + surgical } \\
\text { resection }\end{array}$ & JAKI/2 inhibitor & $\begin{array}{l}\text { Biomarkers of the JAK/STAT3 } \\
\text { signaling pathways }\end{array}$ \\
\hline МСТ02035527 & $\begin{array}{l}\mathrm{I} / \mathrm{Il} \text {, ongoing but not } \\
\text { recruiting }\end{array}$ & $\begin{array}{l}\text { Sorefenib tosylate }+ \\
\quad \text { cisplatin }+ \text { docetaxel }\end{array}$ & Raf inhibitor & $\begin{array}{l}\text { Biomarker analysis (unspecified) } \\
\text { of tumor and blood samples }\end{array}$ \\
\hline NCT0I05I79I & $\begin{array}{l}\text { II, ongoing but not } \\
\text { recruiting }\end{array}$ & Everolimus & mTOR inhibitor & $\begin{array}{l}\text { Tumor and patient-associated } \\
\text { markers of the EGFR/mTOR } \\
\text { pathway (including EGFR, ERK, } \\
\text { Akt, and other markers) }\end{array}$ \\
\hline NCT0I58843I & $\begin{array}{l}\text { II, ongoing but not } \\
\text { recruiting }\end{array}$ & $\begin{array}{l}\text { Bevacizumab }+ \text { cisplatin }+ \\
\text { docetaxel }+ \text { cetuximab } \\
\text { followed by radiation, } \\
\text { bevacizumab }+ \text { cisplatin } \\
+ \text { cetuximab } \pm \text { surgical } \\
\text { resection }\end{array}$ & $\begin{array}{l}\text { Anti-vascular endothelial growth } \\
\text { factor (VEGF) monoclonal } \\
\text { antibody; anti-EGFR monoclonal } \\
\text { antibody }\end{array}$ & $\begin{array}{l}\text { EGFR and angiogenesis } \\
\text { biomarkers }\end{array}$ \\
\hline NCT02769520 & II, recruiting & Pembrolizumab or placebo & Anti-PD-I monoclonal antibody & Biomarkers unspecified \\
\hline NCT0I3I6757 & $\begin{array}{l}\text { II, ongoing but not } \\
\text { recruiting }\end{array}$ & $\begin{array}{l}\text { Erlotinib + cetuximab + } \\
\quad \text { paclitaxel + carboplatin }\end{array}$ & $\begin{array}{l}\text { EGFR inhibitor; anti-EGFR } \\
\text { monoclonal antibody }\end{array}$ & EGFR and related biomarkers \\
\hline NCT0I0I6769 & $\begin{array}{l}\mathrm{I} / \mathrm{Il} \text {, ongoing but not } \\
\text { recruiting }\end{array}$ & $\begin{array}{l}\text { Temsirolimus }+ \text { paclitaxel }+ \\
\text { carboplatin }\end{array}$ & mTOR inhibitor & $\begin{array}{l}\text { Biomarkers associated with } \\
\text { resistance to mTOR inhibition }\end{array}$ \\
\hline NCT0274I570 & III, recruiting & $\begin{array}{l}\text { Nivolumab }+ \text { ipilimumab }+ \\
\text { cetuximab }+ \text { cisplatin }+ \\
\text { carboplatin }+ \text { fluorouracil }\end{array}$ & $\begin{array}{l}\text { Anti-PD-I monoclonal antibody; } \\
\text { anti-PD-I monoclonal antibody; } \\
\text { anti-EGFR monoclonal antibody }\end{array}$ & $\begin{array}{l}\text { Assessing baseline PD-LI } \\
\text { expression as a predictive } \\
\text { biomarker }\end{array}$ \\
\hline NCT02952586 & III, recruiting & $\begin{array}{l}\text { Avelumab }+ \text { cisplatin }+ \\
\text { radiation therapy }\end{array}$ & Anti-PD-I monoclonal antibody & $\begin{array}{l}\text { Biomarkers including PD-LI } \\
\text { expression and tumor- } \\
\text { infiltrating CD8+ T } \\
\text { lymphocytes }\end{array}$ \\
\hline NCT02499I20 & II, recruiting & $\begin{array}{l}\text { Cetuximab + palbociclib or } \\
\text { placebo }\end{array}$ & $\begin{array}{l}\text { Anti-EGFR monoclonal antibody; } \\
\text { CDK } 4 / 6 \text { inhibitor }\end{array}$ & $\begin{array}{l}\text { Biomarkers including } \mathrm{p} \mid 6, \mathrm{Rb} \text {, } \\
\text { others }\end{array}$ \\
\hline
\end{tabular}

Contrary to initial suggestions that immunosuppressive agents may work to inhibit the mTOR pathway, recent evidence suggests that mTOR inhibition may instead increase immune activation (Wang et al. 2014). Such results support a co-targeting approach involving mTOR inhibition in combination with an immune checkpoint inhibitor, since mTOR inhibition may potentiate the effects of PD-1 blockade. This is further supported by a study by Moore et al. (2016) showing CD8 T-cell-dependent anti-tumor effects of co-therapy with rapamycin and anti-PD-L1 monoclonal antibody.

Another potential therapeutic combination with the aim of enhancing response to the recently FDA-approved PD-1 inhibitors is combination therapy with HDAC inhibitors. HDAC inhibitors have a poor track record of efficacy as single agents, but the use of these drugs in combination therapy with other
HNSCC treatments is still being evaluated (Blumenschein et al. 2008). A phase I/II clinical trial assessing the safety, tolerability, and efficacy of pembrolizumab and the HDAC inhibitor vorinostat for treatment of HNSCC and salivary gland cancer is ongoing (NCT02538510).

\section{Conclusion and Future Perspectives}

In recent years, our knowledge of the genomic factors underlying HNSCC has expanded tremendously. Despite this information, treatment of this disease has seen little advancement, and the few FDA-approved molecular targeting agents are only effective in a subset of these tumors. Challenges to integrating genomics and therapy include the paucity of FDA-approved drugs to candidate targets, toxicities of agents (alone and/or in 
Table 3. Currently Active Clinical Trials Evaluating Molecular Targeting Agents with Biomarker Inclusion Criteria.

\begin{tabular}{|c|c|c|c|c|}
\hline NCT & Phase & Interventions & Molecular Targeting Roles & Inclusion Criteria Genetics \\
\hline NCT0270669I & $\begin{array}{l}\text { II, not yet } \\
\text { recruiting }\end{array}$ & BGJ398 & Pan FGFR kinase inhibitor & $\begin{array}{l}\text { Using a presence of specific biomarkers } \\
\text { (fibroblast growth factor receptor } \\
\text { gene amplifications, mutations or } \\
\text { translocations) likely predictive of } \\
\text { treatment response as inclusion } \\
\text { criteria; this may be especially } \\
\text { important in a single-agent study }\end{array}$ \\
\hline NCT02644I 22 & II, recruiting & SFII 26 & $\begin{array}{l}\text { Dual PI3K and bromodomain } \\
\text { inhibitor }\end{array}$ & $\begin{array}{l}\text { PIK3CA, PIK3CG, PIK3RI, PIK3R5, } \\
\text { PIK3API, AKT, mTOR, PTEN } \\
\text { *Not PIK3CA amplification }\end{array}$ \\
\hline NCT02822482 & $\mathrm{I} / \mathrm{II}$, recruiting & Copanlisib + cetuximab & $\begin{array}{l}\text { PI3K inhibitor; anti-EGFR } \\
\text { monoclonal antibody }\end{array}$ & $\begin{array}{l}\text { PI3K mutation, PI3K amplification, PTEN } \\
\text { loss }\end{array}$ \\
\hline NCT03292250 & II, recruiting & $\begin{array}{l}\text { BYL7I9 or poziotinib or } \\
\text { nintedanib or abemaciclib } \\
\text { or durvalumab } \pm \\
\text { tremelimumab }\end{array}$ & $\begin{array}{l}\text { PI3K inhibitor; EGFR, HER2, HER4 } \\
\text { inhibitor; VEGFR, FGFR, PDGFR } \\
\text { inhibitor; CDK4/6 inhibitor; } \\
\text { anti-PD-I monoclonal antibody; } \\
\text { anti-CTLA-4 monoclonal } \\
\text { antibody }\end{array}$ & $\begin{array}{l}\text { NBS-based molecular characterization of } \\
\text { each tumor to determine treatment } \\
\text { arm; if no relevant genetic alteration, } \\
\text { patient allocated to the durvalumab } \\
\pm \text { tremelimumab arm regardless of } \\
\text { PD-LI status }\end{array}$ \\
\hline NCT03088059 & $\begin{array}{l}\text { II, not yet } \\
\text { recruiting }\end{array}$ & $\begin{array}{l}\text { Afatinib or palbociclib or } \\
\text { monalizumab or standard } \\
\text { of care }\end{array}$ & $\begin{array}{l}\text { EGFR, HER2 inhibitor; CDK4/6 } \\
\text { inhibitor; anti-NKG2A (natural } \\
\text { killer cell inhibitory receptor) } \\
\text { monoclonal antibody }\end{array}$ & $\begin{array}{l}\text { Treatment arm determined by potential } \\
\text { biomarkers identified in tumor biopsy }\end{array}$ \\
\hline
\end{tabular}

combination), and the limitations of preclinical models. Because of the highly heterogeneous nature of this disease, genomic information instead needs to be used to create personalized therapeutics, specific to the genomic landscape of individual cancers. Overall, randomized clinical trials of molecular targeting agents that show promise in animal models often exhibit limited or no significant efficacy in HNSCC patients. Incorporation of candidate predictive biomarkers ("basket" oncology trials) is likely to increase success rates. Drug resistance to targeted therapies ultimately limits their efficacy. Improved understanding of resistance mechanisms will allow testing of combination therapies to prevent and/or delay resistance. Knowledge of the tumor mutational profile has the potential to impact radiomics, in which differential gene expression is used to adjust radiation doses (Scott et al. 2017).

One of the first steps toward the application of precision medicine in standard-of-care practice may be the integration of next-generation sequencing for tumor profiling into routine clinical management. Where feasible, this profiling could lead to subsequent enrollment of patients into matched clinical trials based on their tumor profiles, a technique that has demonstrated increased experimental treatment response rates (Chau et al. 2016). Integration of standard-of-care tumor profiling in HNSCC, shown to be achievable and advantageous by Chau et al. (2016), would allow for the increased feasibility of biomarker-driven clinical trials. Consequently, once molecular targeting drugs and their predictive biomarkers are identified and validated, this approach would also ease the transition between current routine practice and precision medicine.

\section{Author Contributions}

J.D. Kemmer, contributed to conception, design, data acquisition, analysis, and interpretation, drafted the manuscript; J.R. Grandis, D.E. Johnson, contributed to conception and design, critically revised the manuscript. All authors gave final approval and agree to be accountable for all aspects of the work.

\section{Acknowledgments}

This work was supported by National Institutes of Health grants R01 DE24728 (D.E.J.) and the American Cancer Society and R01 DE023685 (J.R.G.). The authors declare no potential conflicts of interest with respect to the authorship and/or publication of this article.

\section{References}

Agrawal N, Frederick MJ, Pickering CR, Bettegowda C, Chang K, Li RJ, Fakhry C, Xie T, Zhang J, Wang J, et al. 2011. Exome sequencing of head and neck squamous cell carcinoma reveals inactivating mutations in NOTCH1. Science. 333(6046):1154-1157.

Almeida LO, Abrahao AC, Rosselli-Murai LK, Giudice FS, Zagni C, Leopoldino AM, Squarize CH, Castilho RM. 2014. NFКB mediates cisplatin resistance through histone modifications in head and neck squamous cell carcinoma (HNSCC). FEBS Open Bio. 4(1):96-104.

Ando M, Kawazu M, Ueno T, Fukumura K, Yamato A, Soda M, Yamashita Y, Choi YL, Yamasoba T, Mano H. 2013. Cancer-associated missense mutations of caspase- 8 activate nuclear factor- $\kappa \mathrm{B}$ signaling. Cancer Sci. 104(8): 1002-1008.

Ang KK, Harris J, Wheeler R, Weber R, Rosenthal DI, Nguyen-Tân PF, Westra WH, Chung CH, Jordan RC, Lu C, et al. 2010. Human papillomavirus and survival of patients with oropharyngeal cancer. N Engl J Med. 363(1):24 35 .

Asokan GS, Jeelani S, Gnanasundaram N. 2014. Promoter hypermethylation profile of tumour suppressor genes in oral leukoplakia and oral squamous cell carcinoma. J Clin Diagn Res. 8(10):ZC09.

Baylin SB. 1997. Tying it all together: epigenetics, genetics, cell cycle, and cancer. Science. 277(5334):1948-1949.

Biktasova AK, Hajek M, Sewell AB, Gary CS, Bellinger G, Deshpande H, Bhatia AK, Burtness BA, Judson BL, Mehra S, et al. 2017. Demethylation therapy as a targeted treatment for human papilloma virus-associated head and neck cancer. Clin Cancer Res. 23(23):7276-7287.

Blumenschein GR, Kies MS, Papadimitrakopoulou VA, Lu C, Kumar AJ, Ricker JL, Chiao JH, Chen C, Frankel SR. 2008. Phase II trial of the histone deacetylase inhibitor vorinostat (zolinza, suberoylanilide hydroxamic acid, SAHA) in patients with recurrent and/or metastatic head and neck cancer. Invest New Drugs. 26(1):81-87. 
Bonner JA, Harari PM, Giralt J, Cohen RB, Jones CU, Sur RK, Raben D, Baselga J, Spencer SA, Zhu J, et al. 2010. Radiotherapy plus cetuximab for locoregionally advanced head and neck cancer: 5 -year survival data from a phase 3 randomised trial, and relation between cetuximab-induced rash and survival. Lancet Oncol. 11(1):21-28.

Bozec A, Ebran N, Radosevic-Robin N, Chamorey E, Yahia HB, Marcie S, Gautier M, Penault-Llorca F, Milano G. 2017. Combination of phosphotidylinositol-3-kinase targeting with cetuximab and irradiation: a preclinical study on an orthotopic xenograft model of head and neck cancer. Head Neck. 39(1):151-159.

Bozec A, Ebran N, Radosevic-Robin N, Sudaka A, Monteverde M, Toussan N, Etienne-Grimaldi M, Nigro CL, Merlano M, Penault-Llorca F, et al. 2016. Combination of mTOR and EGFR targeting in an orthotopic xenograft model of head and neck cancer. Laryngoscope. 126(4):156-163.

Braig F, Kriegs M, Voigtlaender M, Habel B, Grob T, Biskup K, Blanchard V, Sack M, Thalhammer A, Ben Batalla I, et al. 2017. Cetuximab resistance in head and neck cancer is mediated by EGFR-K521 polymorphism. Cancer Res. 77(5):1188-1199.

Carlander AF, Grønhøj Larsen C, Jensen DH, Garnæs E, Kiss K, Andersen L, Olsen CH, Franzmann M, Høgdall E, Kjær SK, et al. 2017. Continuing rise in oropharyngeal cancer in a high HPV prevalence area: a Danish population-based study from 2011 to 2014. Eur J Cancer. 70:75-82.

Castellano E, Downward J. 2011. RAS interaction with PI3K: more than reprints and permission: Genes Cancer. 2(3):261-274.

Cerami E, Gao J, Dogrusoz U, Gross BE, Sumer SO, Aksoy BA, Jacobsen A, Byrne CJ, Heuer ML, Larsson E, et al. 2012. The cBio cancer genomics portal: an open platform for exploring multidimensional cancer genomics data. Cancer Discov. 2(5):401-404.

Chakravarty D, Gao J, Phillips S, Kundra R, Zhang H, Wang J, Rudolph JE, Yaeger R, Soumerai T, Nissan MH, et al. 2017. OncoKB: a precision oncology knowledge base. JCO Precis Oncol [epub ahead of print 16 May 2017] in press. doi:10.1200/PO.17.00011.

Chaturvedi AK, Engels EA, Pfeiffer RM, Hernandez BY, Xiao W, Kim E, Jiang B, Goodman MT, Sibug-Saber M, Cozen W, et al. 2011. Human papillomavirus and rising oropharyngeal cancer incidence in the united states. J Clin Oncol. 29(32):4294-4301.

Chau NG, Li YY, Jo VY, Rabinowits G, Lorch JH, Tishler RB, Margalit DN, Schoenfeld JD, Annino DJ, Goguen LA, et al. 2016. Incorporation of nextgeneration sequencing into routine clinical care to direct treatment of head and neck squamous cell carcinoma. Clin Cancer Res. 22(12):2939-2949.

Chen X, Liu L, Mims J, Punska EC, Williams KE, Zhao W, Arcaro KF, Tsang AW, Zhou X, Furdui CM. 2015. Analysis of DNA methylation and gene expression in radiation-resistant head and neck tumors. Epigenetics. 10(6):545-561.

Chiosea SI, Grandis JR, Lui V, Diergaarde B, Maxwell JH, Ferris RL, Kim SW, Luvison A, Miller A, Nikiforova MN. 2013. PIK3CA, HRAS and PTEN in human papillomavirus positive oropharyngeal squamous cell carcinoma. BMC Cancer. 13(1):602.

Chow LQ, Haddad R, Gupta S, Mahipal A, Mehra R, Tahara M, Berger R, Eder JP, Burtness B, Lee S, et al. 2016. Antitumor activity of pembrolizumab in biomarker-unselected patients with recurrent and/or metastatic head and neck squamous cell carcinoma: results from the phase ib KEYNOTE-012 expansion cohort. J Clin Oncol. 34(32):3838-3845.

Cohen EE, Licitra LF, Burtness B, Fayette J, Gauler T, Clement PM, Grau JJ, Del Campo JM, Mailliez A, Haddad RI, et al. 2017. Biomarkers predict enhanced clinical outcomes with afatinib versus methotrexate in patients with second-line recurrent and/or metastatic head and neck cancer. Ann Oncol. 28(10):2526-2532.

da Costa, Alexandre ABA, D'Almeida Costa F, Ribeiro AR, Guimarães AP, Chinen LT, Lopes CAP, de Lima, Vladmir CC. 2015. Low PTEN expression is associated with worse overall survival in head and neck squamous cell carcinoma patients treated with chemotherapy and cetuximab. Int J Clin Oncol. 20(2):282-289.

Dyson N, Howley PM, Munger K, Harlow E. 1989. The human papilloma virus-16 E7 oncoprotein is able to bind to the retinoblastoma gene product. Science. 243(4893):934-937.

Elkabets M, Pazarentzos E, Juric D, Sheng Q, Pelossof R, Brook S, Benzaken A, Rodon J, Morse N, Yan J, et al. 2015. AXL mediates resistance to PI3Ka inhibition by activating the EGFR/PKC/mTOR axis in head and neck and esophageal squamous cell carcinomas. Cancer Cell. 27(4):533-546.

el-Naggar AK, Lai S, Luna MA, Zhou XD, Weber RS, Goepfert H, Batsakis JG. 1995. Sequential p53 mutation analysis of pre-invasive and invasive head and neck squamous carcinoma. Int J Cancer. 64(3):196-201.

Fakhry C, Westra WH, Li S, Cmelak A, Ridge JA, Pinto H, Forastiere A, Gillison ML. 2008. Improved survival of patients with human papillomavirus-positive head and neck squamous cell carcinoma in a prospective clinical trial. J Natl Cancer Inst. 100(4):261-269.
Feenstra M, Veltkamp M, van Kuik J, Wiertsema S, Slootweg P, van den Tweel J, de Weger R, Tilanus M. 1999. HLA class I expression and chromosomal deletions at $6 p$ and $15 q$ in head and neck squamous cell carcinomas. Tissue Antigens. 54(3):235-245.

Feldman R, Gatalica Z, Knezetic J, Reddy S, Nathan C, Javadi N, Teknos T. 2016. Molecular profiling of head and neck squamous cell carcinoma. Head Neck. 38(suppl 1):E1625-E1638.

Ferris RL, Blumenschein G, Fayette J, Guigay J, Colevas AD, Licitra L, Harrington K, Kasper S, Vokes EE, Even C, et al. 2016. Nivolumab for recurrent squamous-cell carcinoma of the head and neck. N Engl J Med. 375(19): 1856-1867.

Froimchuk E, Jang Y, Ge K. 2017. Histone H3 lysine 4 methyltransferase KMT2D. Gene. 627:337-342.

Gao J, Aksoy BA, Dogrusoz U, Dresdner G, Gross B, Sumer SO, Sun Y, Jacobsen A, Sinha R, Larsson E, et al. 2013. Integrative analysis of complex cancer genomics and clinical profiles using the cBioPortal. Sci Signal. 6(269):pl1.

Geiger JL, Bauman JE, Gibson MK, Gooding WE, Varadarajan P, Kotsakis A, Martin D, Gutkind JS, Hedberg ML, Grandis JR, et al. 2016. Phase II trial of everolimus in patients with previously treated recurrent or metastatic head and neck squamous cell carcinoma. Head Neck. 38(12):1759-1764.

Giudice FS, Pinto DS, Nör JE, Squarize CH, Castilho RM. 2013. Inhibition of histone deacetylase impacts cancer stem cells and induces epithelialmesenchyme transition of head and neck cancer. PLoS ONE. 8(3):e58672.

Hajek M, Sewell A, Kaech S, Burtness B, Yarbrough WG, Issaeva N. 2017. TRAF3/CYLD mutations identify a distinct subset of human papillomavirus-associated head and neck squamous cell carcinoma. Cancer. 123(10):1778-1790.

Haraguchi K, Ohsugi M, Abe Y, Semba K, Akiyama T, Yamamoto T. 2008 Ajuba negatively regulates the wnt signaling pathway by promoting GSK3-mediated phosphorylation of -catenin. Oncogene. 27(3):274-284.

Hashibe M, Brennan P, Chuang S, Boccia S, Castellsague X, Chen C, Curado MP, Dal Maso L, Daudt AW, Fabianova E, et al. 2009. Interaction between tobacco and alcohol use and the risk of head and neck cancer: pooled analysis in the international head and neck cancer epidemiology consortium. Cancer Epidemiol Biomarkers Prev. 18(2):541-550.

Isaacsson Velho PH, Castro G Jr, Gilberto Chung CH. 2015. Targeting the PI3K pathway in head and neck squamous cell carcinoma. Am Soc Clin Oncol Educ Book. 2015:123-128.

Jimeno A, Shirai K, Choi M, Laskin J, Kochenderfer M, Spira A, ClineBurkhardt V, Winquist E, Hausman D, Walker L, et al. 2015. A randomized, phase II trial of cetuximab with or without PX-866, an irreversible oral phosphatidylinositol 3-kinase inhibitor, in patients with relapsed or metastatic head and neck squamous cell cancer. Ann Oncol. 26(3):556-561.

Keren S, Shoude Z, Lu Z, Beibei Y. 2014. Role of EGFR as a prognostic factor for survival in head and neck cancer: a meta-analysis. Tumor Biol 35(3):2285-2295

Keysar SB, Astling DP, Anderson RT, Vogler BW, Bowles DW, Morton JJ, Paylor JJ, Glogowska MJ, Le PN, Eagles-Soukup JR, et al. 2013. A patient tumor transplant model of squamous cell cancer identifies PI3K inhibitors as candidate therapeutics in defined molecular bins. Mol Oncol. 7(4):776-790.

Kim KT, Kim B, Kim JH. 2016. Association between FAT1 mutation and overall survival in patients with human papillomavirus-negative head and neck squamous cell carcinoma. Head Neck. 38(Suppl 1):E2021-E2029.

Koutsimpelas D, Pongsapich W, Heinrich U, Mann S, Mann WJ, Brieger J. 2012. Promoter methylation of MGMT, MLH1 and RASSF1A tumor suppressor genes in head and neck squamous cell carcinoma: pharmacological genome demethylation reduces proliferation of head and neck squamous carcinoma cells. Oncol Rep. 27(4):1135-1141.

Kreimer AR, Clifford GM, Boyle P, Franceschi S. 2005. Human papillomavirus types in head and neck squamous cell carcinomas worldwide: a systematic review. Cancer Epidemiol Biomarkers Prev. 14(2):467-475.

Lattanzio L, Milano G, Monteverde M, Tonissi F, Vivenza D, Merlano M, Lo Nigro C. 2016. Schedule-dependent interaction between temsirolimus and cetuximab in head and neck cancer: A preclinical study. Anticancer Drugs. 27(6):533-539.

Le JM, Squarize CH, Castilho RM. 2014. Histone modifications: targeting head and neck cancer stem cells. World J Stem Cells. 6(5):511-525.

Li C, Egloff AM, Sen M, Grandis JR, Johnson DE. 2014. Caspase-8 mutations in head and neck cancer confer resistance to death receptor-mediated apoptosis and enhance migration, invasion, and tumor growth. Mol Oncol. 8(7):1220-1230.

Licitra L, Mesia R, Rivera F, Remenár E, Hitt R, Erfán J, Rottey S, Kawecki A, Zabolotnyy D, Benasso M, et al. 2011. Evaluation of EGFR gene copy number as a predictive biomarker for the efficacy of cetuximab in combination with chemotherapy in the first-line treatment of recurrent and/or metastatic squamous cell carcinoma of the head and neck: EXTREME study. Ann Oncol. 22(5):1078-1087. 
Lindsay C, Seikaly H, Biron VL. 2017. Epigenetics of oropharyngeal squamous cell carcinoma: Opportunities for novel chemotherapeutic targets. J Otolaryngol Head Neck Surg. 46(1):9.

Lyu J, Song H, Tian Z, Miao Y, Ren G, Guo W. 2016. Predictive value of pAKT/PTEN expression in oral squamous cell carcinoma treated with cetuximab-based chemotherapy. Oral Surg Oral Med Oral Pathol Oral Radiol. 121(1):67-72.

Ma C, Wang J, Fan L, Guo Y. 2017. Inhibition of CD147 expression promotes chemosensitivity in HNSCC cells by deactivating MAPK/ERK signaling pathway. Exp Mol Pathol. 102(1):59-64.

Machiels JH, Haddad RI, Fayette J, Licitra LF, Tahara M, Vermorken JB, Clement PM, Gauler T, Cupissol D, Grau JJ, et al. 2015. Afatinib versus methotrexate as second-line treatment in patients with recurrent or metastatic squamous-cell carcinoma of the head and neck progressing on or after platinum-based therapy (LUX-head \& neck 1): an open-label, randomised phase 3 trial. Lancet Oncol. 16(5):583-594.

Madera D, Vitale-Cross L, Martin D, Schneider A, Molinolo AA, Gangane N, Carey TE, McHugh JB, Komarck CM, Walline HM, et al. 2015. Prevention of tumor growth driven by PIK3CA and HPV oncogenes by targeting mTOR signaling with metformin in oral squamous carcinomas expressing OCT3. Cancer Prev Res (Phila). 8(3):197-207.

Mandal R, Şenbabaoğlu Y, Desrichard A, Havel JJ, Dalin MG, Riaz N, Lee K, Ganly I, Hakimi AA, Chan TA, et al. 2016. The head and neck cancer immune landscape and its immunotherapeutic implications. JCI Insight. 1(17):e89829.

Massagué J. 2008. TGFß in cancer. Cell. 134(2):215-230.

Massarelli E, Lin H, Ginsberg LE, Tran HT, Lee JJ, Canales JR, Williams MD, Blumenschein GR, Lu C, Heymach JV, et al. 2015. Phase II trial of everolimus and erlotinib in patients with platinum-resistant recurrent and/or metastatic head and neck squamous cell carcinoma. Ann Oncol. 26(7):1476-1480

Mazumdar T, Sen B, Wang Y, Peng S, Nicholas C, Glisson BS, Myers JN, Johnson FM. 2015. Drug-induced RAF dimerization is independent of RAS mutation status and does not lead to universal MEK dependence for cell survival in head and neck cancers. Anticancer Drugs. 26(8):835-842.

Mazumdar T, Byers LA, Ng PKS, Mills GB, Peng S, Diao L, Fan Y, StemkeHale K, Heymach JV, Myers JN, et al. 2014. A comprehensive evaluation of biomarkers predictive of response to PI3K inhibitors and of resistance mechanisms in head and neck squamous cell carcinoma. Mol Cancer Ther 13(11):2738-2750.

Michel L, Ley J, Wildes TM, Schaffer A, Robinson A, Chun S, Lee W, Lewis J, Trinkaus K, Adkins D. 2016. Phase I trial of palbociclib, a selective cyclin dependent kinase 4/6 inhibitor, in combination with cetuximab in patients with recurrent/metastatic head and neck squamous cell carcinoma. Oral Oncol. 58:41-48.

Michmerhuizen NL, Leonard E, Kulkarni A, Brenner JC. 2016. Differential compensation mechanisms define resistance to PI3K inhibitors in PIK3CA amplified HNSCC. Otorhinolaryngol Head Neck Surg. 1(2):44-50.

Mohan S, Vander Broek R, Shah S, Eytan DF, Pierce ML, Carlson SG, Coupar JF, Zhang J, Cheng H, Chen Z, et al. 2015. MEK inhibitor PD-032590 overcomes resistance to $\mathrm{PI} 3 \mathrm{~K} / \mathrm{mTOR}$ inhibitor PF-5212384 and potentiates antitumor effects in human head and neck squamous cell carcinoma. Clin Cancer Res. 21(17):3946-3956.

Moore EC, Cash HA, Caruso AM, Uppaluri R, Hodge JW, Van Waes C, Allen CT. 2016. Enhanced tumor control with combination mTOR and PD-L1 inhibition in syngeneic oral cavity cancers. Cancer Immunol Res. 4(7):611-620.

Morris L, Chandramohan R, West L, Zehir A, Chakravarty D, Pfister DG Wong RJ, Lee NY, Sherman EJ, Baxi SS, et al. 2017. The molecular landscape of recurrent and metastatic head and neck cancers: Insights from a precision oncology sequencing platform. JAMA Oncol. 3(2):244-255.

Morris LGT, Kaufman AM, Gong Y, Ramaswami D, Walsh LA, Turcan Ş, Eng S, Kannan K, Zou Y, Peng L, et al. 2013. Recurrent somatic mutation of FAT1 in multiple human cancers leads to aberrant wnt activation. Nat Genet. 45(3):253-261.

Mriouah J, Boura C, Gargouri M, Plenat F, Faivre B. 2014. PTEN expression is involved in the invasive properties of HNSCC: a key protein to consider in locoregional recurrence. Int J Oncol. 44(3):709-716.

Papillon-Cavanagh S, Lu C, Gayden T, Mikael LG, Bechet D, Karamboulas C, Ailles L, Karamchandani J, Marchione DM, Garcia BA, et al. 2017. Impaired H3K36 methylation defines a subset of head and neck squamous cell carcinomas. Nat Genet. 49(2):180-185.

Pedrero JMG, Carracedo DG, Pinto CM, Zapatero AH, Rodrigo JP, Nieto CS, Gonzalez MV. 2005. Frequent genetic and biochemical alterations of the PI 3-K/AKT/PTEN pathway in head and neck squamous cell carcinoma. Int J Cancer. 114(2):242-248
Pickering CR, Zhang J, Yoo SY, Bengtsson L, Moorthy S, Neskey DM, Zhao M, Ortega Alves MV, Chang K, Drummond J, et al. 2013. Integrative genomic characterization of oral squamous cell carcinomaidentifies frequent somatic drivers. Cancer Discov. 3(7):770-781.

Psyrri A, Lee J, Pectasides E, Vassilakopoulou M, Kosmidis EK, Burtness BA, Rimm DL, Wanebo HJ, Forastiere AA. 2014. Prognostic biomarkers in phase II trial of cetuximab-containing induction and chemoradiation in resectable HNSCC: Eastern Cooperative Oncology Group E2303. Clin Cancer Res. 20(11):3023-3032.

Puram SV, Rocco JW. 2015. Molecular aspects of head and neck cancer therapy. Hematol Oncol Clin North Am. 29(6):971-992.

Qiu W, Schönleben F, Li X, Ho DJ, Close LG, Manolidis S, Bennett BP, Su GH. 2006. PIK3CA mutations in head and neck squamous cell carcinoma. Clin Cancer Res. 12(5):1441-1446.

Rothenberg SM, Ellisen LW. 2012. The molecular pathogenesis of head and neck squamous cell carcinoma. J Clin Invest. 122(6):1951-1957.

Scheffner M, Werness BA, Huibregtse JM, Levine AJ, Howley PM. 1990. The E6 oncoprotein encoded by human papillomavirus types 16 and 18 promotes the degradation of p53. Cell. 63(6):1129-1136.

Scott JG, Berglund A, Schell MJ, Mihaylov I, Fulp WJ, Yue B, Welsh E, Caudell JJ, Ahmed K, Strom TS, et al. 2017. A genome-based model for adjusting radiotherapy dose (GARD): a retrospective, cohort-based study. Lancet Oncol. 18(2):202-211.

Seiwert TY, Fayette J, Cupissol D, Del Campo JM, Clement PM, Hitt R, Degardin M, Zhang W, Blackman A, Ehrnrooth E, et al. 2014. A randomized, phase II study of afatinib versus cetuximab in metastatic or recurrent squamous cell carcinoma of the head and neck. Ann Oncol. 25(9):18131820.

Seiwert TY, Burtness B, Mehra R, Weiss J, Berger R, Eder JP, Heath K, McClanahan T, Lunceford J, Gause C, et al. 2016. Safety and clinical activity of pembrolizumab for treatment of recurrent or metastatic squamous cell carcinoma of the head and neck (KEYNOTE-012): an open-label, multicentre, phase $1 \mathrm{~b}$ trial. Lancet Oncol. 17(7):956-965.

Seiwert TY, Zuo Z, Keck MK, Khattri A, Pedamallu CS, Stricker T, Brown C, Pugh TJ, Stojanov P, Cho J, et al. 2015. Integrative and comparative genomic analysis of HPV-positive and HPV-negative head and neck squamous cell carcinomas. Clin Cancer Res. 21(3):632-641.

She Y, Nong X, Zhang M, Wang M. 2017. Epstein-Barr virus infection and oral squamous cell carcinoma risk: a meta-analysis. PLoS One. 12(10): 0186860 .

Shepard HM, Brdlik CM, Schreiber H. 2008. Signal integration: a framework for understanding the efficacy of therapeutics targeting the human EGFR family. J Clin Invest. 118(11):3574-3581.

Siegel RL, Miller KD, Jemal A. 2017. Cancer statistics, 2017. CA Cancer J Clin. 67(1):7-30.

Silva-Oliveira RJ, Melendez M, Martinho O, Zanon MF, de Souza Viana L, Carvalho AL, Reis RM. 2017. AKT can modulate the in vitro response of HNSCC cells to irreversible EGFR inhibitors. Oncotarget. 8(32):5328853301

Simpson DR, Mell LK, Cohen EEW. 2015. Targeting the PI3K/AKT/mTOR pathway in squamous cell carcinoma of the head and neck. Oral Oncol. 51(4):291-298.

Soulières D, Faivre S, Mesía R, Remenár É, Li S, Karpenko A, Dechaphunkul A, Ochsenreither S, Kiss LA, Lin J, et al. 2017. Buparlisib and paclitaxel in patients with platinum-pretreated recurrent or metastatic squamous cell carcinoma of the head and neck (BERIL-1): a randomised, double-blind, placebo-controlled phase 2 trial. Lancet Oncol. 18(3):323-335.

Stransky N, Egloff AM, Tward AD, Kostic AD, Cibulskis K, Sivachenko A, Kryukov GV, Lawrence MS, Sougnez C, McKenna A, et al. 2011. The mutational landscape of head and neck squamous cell carcinoma. Science. 333(6046):1157-1160

Sun W, Gaykalova DA, Ochs MF, Mambo E, Arnaoutakis D, Liu Y, Loyo M, Agrawal N, Howard J, Li R, et al. 2014. Activation of the NOTCH pathway in head and neck cancer. Cancer Res. 74(4):1091-1104.

The Cancer Genome Atlas Network. 2015. Comprehensive genomic characterization of head and neck squamous cell carcinomas. Nature. 517(7536):576-582.

Torre LA, Bray F, Siegel RL, Ferlay J, Lortet-Tieulent J, Jemal A. 2015. Global cancer statistics, 2012. CA Cancer J Clin. 65(2):87-108.

Vazquez F, Sellers WR. 2000. The PTEN tumor suppressor protein: an antagonist of phosphoinositide 3-kinase signaling. Biochim Biophys Acta. 1470(1):21-35.

Vermorken JB, Mesia R, Rivera F, Remenar E, Kawecki A, Rottey S, Erfan J, Zabolotnyy D, Kienzer H, Cupissol D, et al. 2008. Platinum-based chemotherapy plus cetuximab in head and neck cancer. N Engl J Med. 359(11):1116-1127. 
Bhatia V, Goel MM, Makker A, Tewari S, Yadu A, Shilpi P, Kumar S, Agarwal SP, Goel SK. 2014. Promoter region hypermethylation and mRNA expression of MGMT and p16 genes in tissue and blood samples of human premalignant oral lesions and oral squamous cell carcinoma. Biomed Res Int. 2014:248419.

Wang Z, Martin D, Molinolo AA, Patel V, Iglesias-Bartolome R, Degese MS, Vitale-Cross L, Chen Q, Gutkind JS. 2014. mTOR co-targeting in cetuximab resistance in head and neck cancers harboring PIK3CA and RAS mutations. J Natl Cancer Inst. 106(9):pii:dju215.

Weidhaas JB, Harris J, Schaue D, Chen AM, Chin R, Axelrod R, El-Naggar AK, Singh AK, Galloway TJ, Raben D, et al. 2017. The KRAS-variant and cetuximab response in head and neck squamous cell cancer: a secondary analysis of a randomized clinical trial. JAMA Oncol. 3(4):483-491.
Yap L, Lee D, Khairuddin A, Pairan M, Puspita B, Siar C, Paterson I. 2015. The opposing roles of NOTCH signalling in head and neck cancer: a mini review. Oral Dis. 21(7):850-857.

Yen Y, Lin C, Lin S, Lin Y, Weng S. 2015. Effect of metformin on the incidence of head and neck cancer in diabetics. Head Neck. 37(9):12681273.

Zehir A, Benayed R, Shah RH, Syed A, Middha S, Kim HR, Srinivasan P, Gao J, Chakravarty D, Devlin SM, et al. 2017. Mutational landscape of metastatic cancer revealed from prospective clinical sequencing of 10,000 patients. Nat Med. 23(6):703-713.

Zolkind P, Uppaluri R. 2017. Checkpoint immunotherapy in head and neck cancers. Cancer Metastasis Rev. 36(3):475-489. 